\title{
Integrative effect of NPK fertilization and weed management practices on growth indices and yield of wheat under agro-climatic condition of Quetta- Pakistan
}

\author{
Muhammad Ayub Babar ${ }^{1 *}$, Ajmal Khan², Ahmed Jan², Sher Azam², \\ Ikramullah $^{4}$ and Muhammad Arif ${ }^{5}$ \\ 1. Directorate of Agriculture Research Vegetable Seed Production Farm ARI Sariab Quetta-Pakistan \\ 2. Balochistan Agriculture College Quetta-Pakistan \\ 3. Directorate of Agriculture Research Cereal Crops ARI Sariab Quetta-Pakistan \\ 4. Directorate of Agriculture Research Usta Muhammad-Pakistan \\ 5. Directorate of Agriculture Research (Pulses) ARI Sariab Quetta-Pakistan \\ *Corresponding author's email: mhdayubbabar@gmail.com \\ Citation \\ Muhammad Ayub Babar, Ajmal Khan, Ahmed Jan, Sher Azam, Ikramullah and Muhammad Arif. Integrative \\ effect of NPK fertilization and weed management practices on growth indices and yield of wheat under agro- \\ climatic condition of Quetta-Pakistan. Pure and Applied Biology. Vol. 8, Issue 1, pp942-959.
}

http://dx.doi.org/10.19045/bspab.2019.80036

\begin{tabular}{llll}
\hline \hline Received: 06/12/2018 & Revised: 04/03/2019 & Accepted: 07/03/2019 & Online First: 26/03/2019 \\
\hline
\end{tabular}

\section{Abstract}

The inhibitory effect of weeds on crop can be minimized by changing nutrient supply and weed management practices. For this purpose, a field experiments was carried out during 2014-15 at the experimental field of ARI, Quetta based on complete randomized block design in factorial arrangement and were replicated thrice. In the experiment, five fertilizer rates $(0-0-0,100-80-50,135-$ 90-50, 170-100-50, 205-110-50 NPK kg ha-1) were tested across different weed management practices (no weeding, herbicide application, hand hoeing and allelopathic weed control) in an integrated manner. The results showed that the medium fertilizer rate (135-90-50 kg NPK ha-1) produced maximum tillers $\mathrm{m}^{-2}$ (437.50), spike length $(12.12 \mathrm{~cm})$, spikelets spike ${ }^{-1}(29.08)$, grain spike ${ }^{-1}(78.33)$, seed index $(42.05 \mathrm{~g})$, harvest index $(37.7 \%)$, grain yield $\left(4.51 \mathrm{t} \mathrm{ha}^{-1}\right)$, leaf $\mathrm{N}(3.91 \%), \mathrm{P}(0.94 \%)$ and $\mathrm{K}$ (4.05) concentration and uptake. The increasing fertilizer rates particularly $\mathrm{N}$ increased vegetative growth over reproductive growth as evidenced from higher LA $\left(316.92 \mathrm{~cm}^{-2} \mathrm{plant}^{-1}\right)$ and LAI (1.96). In case of weeds management, the herbicide application or hand hoeing effectively controlled weeds by 85.47 and $78.73 \%$ that resulted in increased all wheat traits. According to linear regression analysis, grain yield was positively and significantly associated with LAI $(r=0.93)$, tillers $\mathrm{m}^{-2}(\mathrm{r}=$ $0.94)$, harvest index $(r=0.96)$, LAD $(r=0.97)$ and NAR $(r=0.88)$ respectively. Consequently, weed crop competition was minimized and wheat yield was enhanced when fertilizer rate of 135-90-50 NPK kg ha ${ }^{-1}$ was used and weeds were controlled either by herbicide application/hand hoeing.

Keywords: Allelopathic weed control; Growth indices; Herbicide; Interculture; NPK fertilizer; Weeds; Wheat

\section{Introduction}

Nutrients play an important role in the growth, development, production and quality of cereal crops including wheat.
Among all essential nutrients, the major nutrients required by wheat crop are nitrogen $(\mathrm{N})$, phosphorus $(\mathrm{P})$ and potassium (K). Among the macronutrients, 
$\mathrm{N}$ is required in large amount which is the major nutrient needed for increasing growth and yield of crops and its supply in balanced form is reflected in bumper crop. According to Brady and Weil [1] that the higher $\mathrm{N}$ rates substantially transform carbohydrates into proteins leading to formation of more protoplasm and play key role in overall growth processes. However, the requirement of $\mathrm{P}$ is lower than $\mathrm{N}$ and $\mathrm{K}$ but its role is quite critical in pant growth particularly in early growth stages and is responsible for the transfer of energy during entire growth period. On dry weight basis, the quantity of $\mathrm{P}$ needed is 10 times lower than $\mathrm{N}$ and $\mathrm{K}$. They further stated that $\mathrm{P}$ is essential in many biochemical reactions including photosynthesis, cell division, respiration and others growth processes. In these growth processes, the energy involved is ATP which requires the continuous supply of external $\mathrm{P}$ from soil. And above all, it is beneficial for setting of flowering, seed formation, crop maturity and proliferation of rooting. So, its optimum application improve yield and yield components of wheat.

The grain yield of wheat is tremendously affected by $\mathrm{N}$ application because low applicatioin rate reduce the overall wheat growth and yield and higher application rates enhanced vegetative growth at the cost of reproductive growth that led to low grain yield of wheat [2]. According to Liang et al. [3] that the optimum $\mathrm{N}$ application of $80-120 \mathrm{~kg} \mathrm{ha}^{-1}$ produced improved growth and yield of wheat. Some researchers like Sobh et al. [4], Alam et al. [5] and Kumar et al. [6] reported that $\mathrm{N}$ application rate of $200 \mathrm{~kg}$ $\mathrm{ha}^{-1}$ resulted in enhancement of agronomic and physiological characteristics of wheat. Chauhan [7] revealed that fertilizer rate of 120-60-40 NPK kg ha-1 increased the growth characteristics of wheat as compared to control where no fertilizer was applied. Agronomic traits of wheat were increased when 120 and $150 \mathrm{~kg} \mathrm{~N}$ ha ${ }^{1}$ was applied while the lower and higher rates resulted in reduction of all agronomic traits [8].

The application of phosphorus and potassium to wheat crop is essential. Both $\mathrm{P}$ and $\mathrm{K}$ increases seed maturity and seed development and critical for proliferation of root. Wheat plants with extensive rooting can explore more volume of soil for nutrients absorption [7]. In soil system of Pakistan most of the nutrients are not easily available to crop due to calcareous and alkaline nature of soil and under this situation crop hardly recover only 11-19\% of nutrients applied as fertilizer [9]. It has been observed that the increasing rate of fertilizer exerted beneficial effects on crops particularly wheat and the overall agronomic characteristics of wheat such as plant height, spike length, spikelets spike ${ }^{-1}$, grains spike ${ }^{-1}$, seed index, biological yield, grain yield and harvest index were improved [10]. The application of $108 \mathrm{P}$ $\mathrm{kg} \mathrm{ha}^{-1}$ in wheat crop resulted in increased $\mathrm{P}$ uptake, leaf $\mathrm{P}$ concentration, more tillers $\mathrm{m}^{-2}$ and higher biological and grian yield [11] while in Pakistan the researcher like Khalid et al. [12] observed that the application of $45 \mathrm{~kg} \mathrm{P} \mathrm{ha}^{-1}$ produced higher wheat grain yield and improved the growth of wheat by increasing the yield components and growth indices.

The role of potassium as a quality enhancer in all vegetables, cereals and fruits is evident that its application helps in improving the plant nutrition, create resistance in plants under stress conditions caused by drought, disease and salinity and above all its application improves the storage life of most crops especially cereals and fruits [13]. Bahmanyar and Ranjbar [14] reported that K application to wheat crop resulted in inceased agronomic traits like plant height, seed index, tillers $\mathrm{m}^{-2}$, leaf $\mathrm{K}$ concentration and uptake and ultimately enhanced grian yield. The application of $\mathrm{K}$ improved photosynthetic activities that resulted in yield enhancement [15-17].

However, one of the factors for low nutrient use efficiency of wheat crop is 
weed infestation because they not only compete with wheat crop for nutrient but also for moisture, space and light that ultimately resulting in low wheat production. Weed infestation is one of the major biotic constraints in agriculture production system [18]. It has high competitive potential as compare to crops because they are easily adopted even in the harsh environment with limited resources $[19,20]$. Generally, the competitive interaction between weed and crop is intricate because both are competing for the same resources such as space, moisture, light and nutrients [21,22]. The availability of space is necessary for growth of plants either weed or crop and due to high competitive potential weed can occupy more space in early growth stage and suppress the crops growth [23]. The second most competitive target for both weed and crop is the available moisture which is vital for their growth and as weeds get succeeded in early establishment, can compete more over crop for moisture and thus reduce crop growth [24]. Its incursion considerably affects incomes and product value and sometimes the entire crop failure might be resulted if weed are not controlled properly $[25,26]$. In Pakistan, the annual losses due to weed infestation in wheat crop are estimated higher than Rs. 28 billion [27].

Weed control strategies comprised of Mechanical (physical) and chemical methods such as summer ploughing, hand weeding, hoeing, tillage, mulching and use of herbicides. As compared to physical weed control, chemical weed control is more effective, low cost involved and time saving. Wheat is largely infested by narrow leaves weed which remain dominant over broad leaves weed [28, 29]. The time of herbicides application is very critical as reported by Balyan et al. [30] and Naseer-ud-Din et al. [31] that the application of isoproturon 35 DAS controlled weed effectively but further delay resulted in poor control. In addition, allelopathic approach can be used for weed control because it is ecologically safe, economical and play a vital role in the development of sustainable agriculture $[32,33]$. The application of allelopathic compounds in the form of plant water extract offers an encouraging substitute of chemical herbicides for sustainable and environmentally friendly weed management [34]. Keeping in view the significance of fertilizer rates and weed control in crop production, the present study was aimed to minimize weed crop competition by using NPK fertilizer integrated with weed management practices for enhancement of wheat yield.

\section{Materials and methods}

The experiment was conducted during the year 2014 and 2015 to investigate the influence of different nitrogen $(\mathrm{N})$, phosphorus (P) and potassium (K) fertilizer rates integrated with different weed management practices for enhancement of wheat yield. The experiment was designed in RCBD (randomized complete block design) in factorial arrangement. Four different fertilizer rates (factor-A) were tested across four weed management practices (factor-B) which were replicated thrice while keeping plot size of $48 \mathrm{~m}^{2}$. The details of treatment combinations are given in (Table 1) and that of factor-A and B are as under:

$$
\begin{aligned}
& \text { Factor }(\mathbf{A})=\text { Fertilizer treatments }=\mathbf{0 5} \\
& \text { F1 }=0-0-0 \quad \text { NPK kg ha-1 } \\
& \text { F2 }=100-80-50 \quad \text { NPK kg ha } \\
& \text { F3 }=135-90-50 \quad \text { NPK kg ha } \\
& \text { F4 }=170-100-50 \text { NPK kg ha-1 } \\
& \text { F5 }=205-110-50 \text { NPK kg ha }
\end{aligned}
$$

Factor $(B)=$ Weed management

techniques $=04$

$\mathrm{W} 1=$ No weeding

W2= Herbicides application:

i) Bromoxynil+MCPA@ $@ 750 \mathrm{ml} \mathrm{ha}^{-1}$ for broadleaf weeds

ii) Clodinafop-propargyl @ $300 \mathrm{~g} \mathrm{ha}^{-1}$ for narrowleaf weeds

W3 = Hand hoeing (after first and second irrigation) 
Table 1. Treatment combinations

\begin{tabular}{|l|l|l|l|}
\hline $\mathrm{T} 1=\mathrm{W}_{1} \mathrm{~F}_{1}$ & $\mathrm{~T} 6=\mathrm{W}_{2} \mathrm{~F}_{1}$ & $\mathrm{~T} 11=\mathrm{W}_{3} \mathrm{~F}_{1}$ & $\mathrm{~T} 16=\mathrm{W}_{4} \mathrm{~F}_{1}$ \\
\hline $\mathrm{T} 2=\mathrm{W}_{1} \mathrm{~F}_{2}$ & $\mathrm{~T} 7=\mathrm{W}_{2} \mathrm{~F}_{2}$ & $\mathrm{~T} 12=\mathrm{W}_{3} \mathrm{~F}_{2}$ & $\mathrm{~T} 17=\mathrm{W}_{4} \mathrm{~F}_{2}$ \\
\hline $\mathrm{T} 3=\mathrm{W}_{1} \mathrm{~F}_{3}$ & $\mathrm{~T} 8=\mathrm{W}_{2} \mathrm{~F}_{3}$ & $\mathrm{~T} 13=\mathrm{W}_{3} \mathrm{~F}_{3}$ & $\mathrm{~T} 18=\mathrm{W}_{4} \mathrm{~F}_{3}$ \\
\hline $\mathrm{T} 4=\mathrm{W}_{1} \mathrm{~F}_{4}$ & $\mathrm{~T} 9=\mathrm{W}_{2} \mathrm{~F}_{4}$ & $\mathrm{~T} 14=\mathrm{W}_{3} \mathrm{~F}_{4}$ & $\mathrm{~T} 19=\mathrm{W}_{4} \mathrm{~F}_{4}$ \\
\hline $\mathrm{T} 5=\mathrm{W}_{1} \mathrm{~F}_{5}$ & $\mathrm{~T} 10=\mathrm{W}_{2} \mathrm{~F}_{5}$ & $\mathrm{~T} 15=\mathrm{W}_{3} \mathrm{~F}_{5}$ & $\mathrm{~T} 20=\mathrm{W}_{4} \mathrm{~F}_{5}$ \\
\hline
\end{tabular}

\section{Cultural practices}

The field was divided into sub-plots according to the experimental description. Buffer zone was built up between the plots where herbicides were used to control the drifting of herbicides into the no weedy plots. Sowing was carried out on $15^{\text {th }}$ November by single coulter hand drill using seed rate of $125 \mathrm{~kg} \mathrm{ha}^{-1}$. The fertilizers were applied as per treatments under factor A. All the phosphorus as single super phosphate, potassium as murate of potash and $1 / 4$ nitrogen was applied during sowing time. However, remaining nitrogen was applied into split doses during 2nd and 3rd irrigations.

\section{Weed management techniques}

Weed management techniques were adopted as per treatments under factor B. Herbicides were applied for broadleaf weeds on 26 days after sowing and for narrow leaf weeds on 40 days after sowing. Sunflower extract as allelopathic weed control [35] was applied 40 days after sowing.

\section{Soil and plant analysis}

A composite soil samples with depth of 15 $\mathrm{cm}$ were collected from the experimental field and analysed for sol texture, $\mathrm{pH}$, electrical conductivity (EC), organic matter and ammonium bicarbonatediethylenetriaminepentaacetic acid (ABDTPA) extractable phosphorus (P) and potassium (K). Hydrometer method was used for soil textural analysis [36], $\mathrm{pH}$ and EC were determined in 1:5 soil and water suspension at $25{ }^{\circ} \mathrm{C}$ according to the method described by McKeague [37] and McLean [38] and organic matter by oxidizing method $[39,40]$. While, ABDTPA extraction solution was used for extracting $P$ and $K$ [41]. In the clear filtrate of AB-DTPA soil extract, phosphorus was determined on Spectrophotometer at 880 $\mathrm{nm}$ wavelength and potassium on Flame Photometer.

Flag leaf was collected from 10-30 pants in each plot at milking stage. The samples were then put in the paper envelopes, labeled them with permanent marker and delivered to the Laboratory of Soil and Water Testing Laboratory ARI Sariab Quetta the same day and stored them over there at $20{ }^{\circ} \mathrm{C}$ for next coming working day. The samples were decontaminated and washed following the method of Sonneveld \& Dijk [42], oven dried at 80 ${ }^{\circ} \mathrm{C}$, ground to 20 mesh and stored in plastic bags at $4{ }^{\circ} \mathrm{C}$ in the Lab. for target analysis. Weighed $0.5 \mathrm{~g}$ of the prepared plant sample and wet digested using hot sulfuric acid with repeated additions of $30 \%$ hydrogen peroxide $\left(\mathrm{H}_{2} \mathrm{O}_{2}\right)$ until the digestion was completed, then this digest was used for the determination of total nitrogen, phosphorus and potassium [43]. For phosphorus, Pipetted $10 \mathrm{ml}$ of the digest into a $100 \mathrm{ml}$ volumetric flask, added $10 \mathrm{ml}$ ammonium-vanadomolybdate and diluted the solution with Deionized water upto the mark [44]. Then, read the absorbance of the blank, standards, and samples after 30 minutes at $410-\mathrm{nm}$ wavelength on Spectrophotometer. The potassium in the digest was determined directly by Flame Photometer [45]. Total nitrogen was determined by Kjeldhal method [46].

\section{Statistical analysis}

The collected data statistically analysed using analysis of variance and Least Significance Difference (LSD) test at probability $(\mathrm{P})$ level 0.05 was conducted for comparison of mean. Correlation was 
established among the studied parameters as influenced by various treatments. All the statistical analysis was computed on Statistix 8.1 software (Math Soft Inc., Cambridge, MA, USA).

\section{Results}

The pre soil analysis of experimental site revealed that the soil was silty clay loam in texture, non-saline, alkaline in nature, low in organic matter contents $(0.64 \%)$, total nitrogen $(0.032 \%)$ and AB-DTPA extractable phosphorus (2.75 ppm) but high in AB-DTPA extractable potassium $\left(134 \mathrm{mg} \mathrm{kg}^{-1}\right)$. The effect of different fertilizer rates and weed management practices on wheat crop were studied in an integrated manner. Both agronomic and physiological traits of wheat were observed along with nutrient accumulation and uptake across both factors of fertilizer rates and weed management practices. The studied agronomic traits of wheat were included plant height $(\mathrm{cm})$, tillers $\left(\mathrm{m}^{-2}\right)$, spike length $(\mathrm{cm})$, spikelets spike ${ }^{-1}$, grains spike $^{-1}$, seed index $(\mathrm{g})$, biological yield $(\mathrm{t}$ $\left.\mathrm{ha}^{-1}\right)$, grain yield $\left(\mathrm{t} \mathrm{ha}^{-1}\right)$ and harvest index (\%) respectively. Whereas, the physiological traits of wheat were included leaf area $\left(\mathrm{cm}^{2}\right.$ plant $\left.{ }^{-1}\right)$, leaf area index (LAI), leaf area duration (LAD) (days), net assimilation rate (NAR) $\left(\mathrm{g} \mathrm{m}^{-2} \mathrm{day}^{-1}\right)$ and crop growth rate (CGR) $\left(\mathrm{g} \mathrm{m}^{-2}\right.$ day $\left.^{-1}\right)$. Together with that, wheat leaf nutrient concentration (\%) was recorded for nitrogen $(\mathrm{N})$, phosphorus $(\mathrm{P})$ and potassium as well as their uptake $\left(\mathrm{kg} \mathrm{ha}^{-1}\right)$. In control plot where weeds were not controlled but NPK fertilizer was applied, the observations were noted for weed biomass $\left(\mathrm{kg} \mathrm{ha}^{-1}\right)$, weed density $\left(\mathrm{m}^{-2}\right)$ and weed frequency $(\%)$.

\section{Agronomic traits of wheat}

The statistical analysis for all agronomic traits of wheat showed highly significant differences across different fertilizer rates and weed management practices and their interaction. The results indicated that maximum plant height $(86.88 \mathrm{~cm})$, biological yield $\left(12.72 \mathrm{t} \mathrm{ha}^{-1}\right)$, leaf area (316.92 $\mathrm{cm}^{2}$ plant ${ }^{-1}$ ), leaf area index
(1.96), weed biomass (6172.9 $\mathrm{kg} \mathrm{ha}^{-1}$ ), weed density $\left(166 \mathrm{~m}^{-2}\right)$ and weed frequency $(6.29 \%)$ were recorded in plot when higher fertilizer rate of 205-110-50 $\mathrm{kg}$ NPK ha ${ }^{-1}$ was applied and their respective lower values were found in control plot where no fertilizer was applied. However, lower fertilizer rate (100-80-50 kg NPK ha ${ }^{-1}$ ) also improve these traits over control but in comparison to higher fertilizer rates these traits were reduced. In case of other important yield components, the fertilizer rate of 135-90$50 \mathrm{~kg} \mathrm{NPK} \mathrm{ha}{ }^{-1}$ produced higher number of tillers $\mathrm{m}^{-2}$ (437.5), spike length (12.12 $\mathrm{cm})$, spikelets spike ${ }^{-1}$ (29.08), grains spike 1 (78.33), seed index (42.05 g), harvest index (37.78) and grain yield (4.51 $\left.\mathrm{t} \mathrm{ha}^{-1}\right)$ which were found in decreasing trend on higher fertilizer rates while control plot expressed lowers values for these traits (Table 2).

Agronomic traits of wheat crop were significantly $(\mathrm{p}<0.05)$ affected by weed management practices as shown in (Table $3)$. Both chemical weeds control and hand hoeing produced statistically higher but at par results for spike length, spikelets spike ${ }^{-}$ 1 , seed index and harvest index. While biological yield was found at par for chemical weed control and allelopathic weed control. Among them, the maximum plant height $(86.17 \mathrm{~cm})$, seed index $(40.90$ g), biological yield (12.01 t ha-1), harvest index (33.73) and grain yield (4.11 t ha $\left.\mathrm{ha}^{-1}\right)$ were recorded in plot when weeds were controlled by herbicide application. Whereas, weed control by hand hoeing produced greater number of tillers $\mathrm{m}^{-2}$ (425.93), spike length $(12.18 \mathrm{~cm})$, spikelets spike ${ }^{-1}(27.80)$ and grains spike ${ }^{-1}$ (74.67) respectively. However, the weedy check (no weed control) exhibited lower values for all the agronomic traits of wheat. It demonstrates that without weeding the optimum yield of wheat cannot be achieved because in presence weed infestation all yield contributing factors are affected that ultimately affect grain yield of wheat. 
The interactive effect of fertilizer rates and weed management practices on agronomic traits of wheat showed significant $(\mathrm{p}<0.05)$ differences as shown in (Table 4). The interaction of 205-110-50 kg NPK ha ${ }^{-1} \mathrm{x}$ herbicide application expressed higher plant height $(91.25 \mathrm{~cm})$ while maximum number of tillers $\mathrm{m}^{-2}$ (545.00), spike length (13.13 $\mathrm{cm}$ ), spikelets spike ${ }^{-1}$ (33.67) and grains spike (89.67) and seed index (44.43 g) and grain yield $\left(5.12 \mathrm{t} \mathrm{ha}^{-1}\right)$ were recorded at the interactive effect of 135-90-50 kg NPK ha-1 $\mathrm{x}$ hand hoeing. Statistically the grains spike ${ }^{1}$, seed index and grain yield manifested at par differences at the interaction of 135-90$50 \mathrm{~kg}$ NPK ha-1 $\mathrm{x}$ hand hoeing and 135-90$50 \mathrm{~kg}$ NPK $\mathrm{ha}^{-1} \mathrm{x}$ herbicide application. However, greater biological yield was noted at higher fertilizer rates of 170-100-50 and 205-110-50 kg NPK ha-1 with herbicide application, hand hoeing and allelopathic weed management which were statistically at par from each other.

\section{Physiological traits of wheat}

Growth indices of a crop are the best indicators for assessing the effect of fertilizer and weed control strategies. So, in this study different growth indices like leaf area, leaf area index, leaf area duration (LAD), net assimilation rate (NAR) and crop growth rate (CGR) were recorded across the interactive effect of fertilizer rates and weed management practices. The analysis of variance regarding these traits showed significant $(\mathrm{p}<0.05)$ differences for NPK rates and weed control measures and their interaction. The LSD test for mean comparison showed maximum leaf area (316.92 $\mathrm{cm}^{2}$ plant ${ }^{-1}$ ) and leaf area index (1.96) on higher fertilizer rate of 205-110-50 $\mathrm{kg} \mathrm{NPK} \mathrm{ha-1}$ while 'higher leaf area duration (100.43 days), NAR (5.06 $\mathrm{g} \mathrm{m}^{-2}$ day $\left.^{-1}\right)$ and CGR (22.90 $\mathrm{g} \mathrm{m}^{-2} \mathrm{day}^{-1}$ ) were found at fertilizer rate of 135-100-50 kg NPK ha'. Statistically, NAR was at par at both fertilizer rates of 135-100-50 kg NPK ha ${ }^{-1}$ and $170-110-50 \mathrm{~kg} \mathrm{NPK} \mathrm{ha}^{-1}$. Among these traits, LAD, NAR and CGR of wheat started decline on higher fertilizer rates. Furthermore, in control plot all physiological traits were decreased statistically (Table 2).
Like agronomic traits, the studied physiological traits of wheat were also varied significantly $(\mathrm{p}<0.05)$ across different weed management practices. The LSD test for mean comparison revealed maximum leaf area $\left(309.13 \mathrm{~cm}^{2}\right.$ plant $\left.^{-1}\right)$, leaf area index (1.82) and CGR (22.24 $\left.\mathrm{g} \mathrm{m}^{-2} \mathrm{day}^{-1}\right)$ of wheat when weeds were controlled by hand pulling/hoeing which were statistically at par with herbicide weed control. While higher NAR was recorded in plot when weeds were controlled by herbicide application only. In case of control plot where weed infestation was allowed, these traits were suppressed substantially. Allelopathic weed management also helped in improvement of these traits over control but was less effective as compared to herbicide application and hand pulling of weeds (Table 3).

The interactive effect of fertilizer rates and weed management practices showed significant $(p<0.05)$ differences for leaf area, leaf area index, LAD, NAR and CGR as given in (Table 4). The maximum leaf area $\left(352.30 \mathrm{~cm}^{2}\right.$ plant $\left.^{-1}\right)$ and leaf area index (2.63) were found at the interaction of 205110-50 kg NPK ha-1 $\mathrm{x}$ hand pulling weed control which were statistically at par with same fertilizer rate $\mathrm{x}$ herbicide application. In case of LAD and NAR, the interactive effect of 135-90-50 kg NPK ha ${ }^{-1} \mathrm{x}$ herbicide application revealed higher LAD (118.22 days) and NAR (6.20 $\mathrm{g} \mathrm{m}^{-2}$ day $\left.^{-1}\right)$ while greater CGR $\left(25.38 \mathrm{~g} \mathrm{~m}^{-2}\right.$ day $\left.^{-1}\right)$ was note at the same fertilizer rate but with hand pulling weeds control.

\section{Leaf NPK concentration $(\%)$ of wheat}

Wheat leaf NPK concentration were fluctuated significantly $(\mathrm{p}<0.05)$ across different fertilizer regimes (Table 2). The LSD test for comparison of mean $(\mathrm{p}<0.05)$ showed higher N (3.91\%), P (0.94\%) and K concentration $(4.05 \%)$ at fertilizer rate of 135-90-50 kg NPK ha-1. While, minimum leaf $\mathrm{N} \quad(2.48 \%), \quad \mathrm{P}(0.24 \%)$ and $\mathrm{K}$ concentration $(2.93 \%)$ were observed at zero fertilizer rate. Statistically, $N$ and $\mathrm{K}$ concentration at two fertilizer rate of 13590-50 and 170-100-50 kg NPK ha ${ }^{-1}$ were at par while $\mathrm{P}$ concentration at $170-100-50$ and 
205-110-50 kg NPK ha ${ }^{-1}$ was found nonsignificant.

Table 2. Effect of different fertilizer rates on wheat traits and leaf NPK concentration and uptake

\begin{tabular}{|c|c|c|c|c|c|c|c|}
\hline \multirow{2}{*}{ Plant traits } & \multicolumn{5}{|c|}{ Fertilizer rates $\left(\mathrm{N}-\mathrm{P}-\mathrm{K} \mathrm{kg} \mathrm{ha}^{-1}\right)$} & \multirow{2}{*}{ S.E. } & \multirow{2}{*}{$\begin{array}{l}\text { LSD } \\
(5 \%)\end{array}$} \\
\hline & 0-0-0 & 100-80-50 & 135-90-50 & 170-100-50 & 205-110-50 & & \\
\hline Plant height $(\mathrm{cm})$ & $74.45 \mathrm{~d}$ & $81.73 \mathrm{c}$ & $84.54 \mathrm{~b}$ & $85.96 \mathrm{ab}$ & $86.88 \mathrm{a}$ & 0.74 & 1.51 \\
\hline Tillers $\left(\mathrm{m}^{-2}\right)$ & $220.92 \mathrm{e}$ & $332.00 \mathrm{~d}$ & $437.50 \mathrm{a}$ & $398.08 b$ & $365.42 \mathrm{c}$ & 5.71 & 11.55 \\
\hline Spike length $(\mathrm{cm})$ & $9.83 \mathrm{~d}$ & $11.21 \mathrm{c}$ & $12.12 \mathrm{a}$ & $11.58 \mathrm{~b}$ & $11.36 \mathrm{c}$ & 0.10 & 0.20 \\
\hline Spikelets spike $^{-1}$ & $20.83 c$ & $25.33 b$ & $29.08 \mathrm{a}$ & $26.91 \mathrm{ab}$ & $24.83 \mathrm{~b}$ & 1.13 & 2.29 \\
\hline Grains spike $^{-1}$ & $57.08 \mathrm{~b}$ & $66.08 \mathrm{c}$ & $78.33 \mathrm{a}$ & $70.58 \mathrm{~b}$ & $64.92 \mathrm{c}$ & 0.99 & 2.01 \\
\hline Seed index $(\mathrm{g})$ & $34.62 \mathrm{e}$ & $38.94 \mathrm{c}$ & $42.05 \mathrm{a}$ & $41.03 \mathrm{~b}$ & $37.08 \mathrm{~d}$ & 0.37 & 0.76 \\
\hline Biological yield $\left(\mathrm{t} \mathrm{ha}^{-1}\right)$ & $9.83 \mathrm{e}$ & $10.91 d$ & $11.83 \mathrm{c}$ & $12.38 \mathrm{~b}$ & $12.72 \mathrm{a}$ & 0.14 & 0.28 \\
\hline Grain yield $\left(\mathrm{t} \mathrm{ha}^{-1}\right)$ & $1.99 \mathrm{e}$ & $3.51 \mathrm{~d}$ & $4.51 \mathrm{a}$ & $4.10 \mathrm{~b}$ & $3.69 \mathrm{c}$ & 0.06 & 0.13 \\
\hline Harvest index (\%) & $20.24 d$ & $32.08 \mathrm{~b}$ & $37.78 \mathrm{a}$ & $32.53 b$ & $28.70 \mathrm{c}$ & 0.43 & 0.86 \\
\hline Leaf area $\left(\mathrm{cm}^{2}\right.$ plant $\left.^{-1}\right)$ & 248.13 & $277.33 c$ & $284.41 b c$ & $295.11 b$ & $316.92 \mathrm{a}$ & 5.57 & 11.27 \\
\hline Leaf area index & $0.72 \mathrm{e}$ & $1.24 \mathrm{~d}$ & $1.47 \mathrm{c}$ & $1.64 \mathrm{~b}$ & $1.96 \mathrm{a}$ & 0.07 & 0.14 \\
\hline Leaf area duration (days) & $48.93 \mathrm{~d}$ & $80.97 \mathrm{c}$ & $100.43 a$ & $87.68 \mathrm{~b}$ & $82.31 \mathrm{c}$ & 2.65 & 5.36 \\
\hline $\begin{array}{l}\text { Net assimilation rate (g } \\
\left.\mathrm{m}^{-2} \mathrm{day}^{-1}\right)\end{array}$ & $3.18 \mathrm{~d}$ & $4.34 b$ & $5.06 \mathrm{a}$ & $4.86 \mathrm{a}$ & $3.66 \mathrm{c}$ & 0.15 & 0.30 \\
\hline $\begin{array}{c}\text { Crop growth rate }\left(\mathrm{g} \mathrm{m}^{-2}\right. \\
\left.\text { day }^{-1}\right)\end{array}$ & $17.64 \mathrm{e}$ & $20.63 c$ & $22.90 \mathrm{a}$ & $21.81 \mathrm{~b}$ & $19.31 d$ & 0.49 & 0.98 \\
\hline Weed biomass $\left(\mathrm{kg} \mathrm{ha}^{-1}\right)$ & $4538.1 d$ & $4633.5 \mathrm{~d}$ & $5377.9 \mathrm{c}$ & $5844.1 \mathrm{~b}$ & $6172.9 \mathrm{a}$ & 107.5 & 217.8 \\
\hline Weed density $\left(\mathrm{m}^{-2}\right)$ & $96.92 \mathrm{e}$ & $108.58 \mathrm{~d}$ & $144.67 \mathrm{c}$ & $158.92 b$ & $166.00 \mathrm{a}$ & 2.89 & 5.85 \\
\hline Weed frequency $(\%)$ & $5.13 \mathrm{c}$ & $5.85 b$ & $6.06 \mathrm{ab}$ & $6.26 \mathrm{a}$ & $6.29 \mathrm{a}$ & 0.13 & 0.26 \\
\hline $\mathrm{N}(\%)$ & $2.48 \mathrm{c}$ & $2.94 \mathrm{~b}$ & $3.91 \mathrm{a}$ & $3.77 \mathrm{a}$ & $3.02 \mathrm{~b}$ & 0.17 & 0.34 \\
\hline $\mathrm{P}(\%)$ & $0.24 \mathrm{~d}$ & $0.39 \mathrm{c}$ & $0.94 \mathrm{a}$ & $0.56 \mathrm{~b}$ & $0.52 \mathrm{~b}$ & 0.03 & 0.06 \\
\hline $\mathrm{K}(\%)$ & $2.93 \mathrm{c}$ & $3.38 \mathrm{~b}$ & $4.05 \mathrm{a}$ & $3.92 \mathrm{a}$ & $3.44 \mathrm{~b}$ & 0.17 & 0.34 \\
\hline N-uptake $\left(\mathrm{kg} \mathrm{ha}^{-1}\right)$ & $83.15 d$ & $98.62 \mathrm{c}$ & $123.23 \mathrm{a}$ & $113.69 \mathrm{~b}$ & $107.0 \mathrm{bc}$ & 4.14 & 8.38 \\
\hline P-uptake $\left(\mathrm{kg} \mathrm{ha}^{-1}\right)$ & $6.83 \mathrm{c}$ & $16.14 \mathrm{~b}$ & $20.51 \mathrm{a}$ & $20.44 a$ & $20.38 \mathrm{a}$ & 0.89 & 1.80 \\
\hline K-uptake $\left(\mathrm{kg} \mathrm{ha}^{-1}\right)$ & $48.18 \mathrm{~d}$ & $75.08 \mathrm{c}$ & $109.81 \mathrm{a}$ & $105.20 \mathrm{ab}$ & $100.36 b$ & 3.78 & 7.66 \\
\hline
\end{tabular}

In each row, means followed by common letter are not significantly different at 5\% probability level

Table 3. Effect of different weed management practices on wheat traits and leaf NPK concentration and uptake

\begin{tabular}{|c|c|c|c|c|c|c|}
\hline \multirow[t]{2}{*}{ Plant traits } & \multicolumn{4}{|c|}{ Weed management practices } & \multirow{2}{*}{ S.E. } & \multirow{2}{*}{$\operatorname{LSD}(5 \%)$} \\
\hline & $\mathrm{W}_{1}$ & $\mathrm{~W}_{2}$ & $\mathrm{~W}_{3}$ & $\mathrm{~W}_{4}$ & & \\
\hline Plant height $(\mathrm{cm})$ & $78.04 \mathrm{~d}$ & $86.17 \mathrm{a}$ & $84.42 \mathrm{~b}$ & $82.22 \mathrm{c}$ & 0.67 & 1.34 \\
\hline Tillers $\left(\mathrm{m}^{-2}\right)$ & $179.93 \mathrm{~d}$ & $406.13 b$ & $425.93 \mathrm{a}$ & $391.13 c$ & 5.10 & 10.33 \\
\hline Spike length $(\mathrm{cm})$ & $8.99 \mathrm{c}$ & $12.00 \mathrm{a}$ & $12.18 \mathrm{a}$ & $11.71 \mathrm{~b}$ & 0.09 & 0.18 \\
\hline Spikelets spike ${ }^{-1}$ & $19.73 b$ & $27.40 \mathrm{a}$ & $27.80 \mathrm{a}$ & $26.67 \mathrm{a}$ & 1.01 & 2.05 \\
\hline Grains spike $^{-1}$ & $52.93 \mathrm{~d}$ & $72.47 \mathrm{~b}$ & $74.67 \mathrm{a}$ & $69.53 c$ & 0.89 & 1.80 \\
\hline Seed index $(\mathrm{g})$ & $34.91 \mathrm{c}$ & $40.90 \mathrm{a}$ & $40.78 \mathrm{a}$ & $38.39 \mathrm{~b}$ & 0.33 & 0.68 \\
\hline Biological yield $\left(\mathrm{t} \mathrm{ha}^{-1}\right)$ & $10.55 \mathrm{c}$ & $12.01 \mathrm{a}$ & $11.61 \mathrm{~b}$ & $11.96 \mathrm{a}$ & 0.12 & 0.25 \\
\hline Grain yield $\left(\mathrm{t} \mathrm{ha}^{-1}\right)$ & $2.47 \mathrm{~d}$ & $4.11 \mathrm{a}$ & $3.95 b$ & $3.68 \mathrm{c}$ & 0.06 & 0.11 \\
\hline Harvest index $(\%)$ & $23.34 \mathrm{c}$ & $33.73 a$ & $33.48 \mathrm{a}$ & $30.51 \mathrm{~b}$ & 0.38 & 0.77 \\
\hline Leaf area $\left(\mathrm{cm}^{2}\right.$ plant $\left.^{-1}\right)$ & $233.89 \mathrm{c}$ & $302.84 \mathrm{a}$ & $309.13 \mathrm{a}$ & $291.67 b$ & 5.06 & 10.25 \\
\hline Leaf area index & $0.52 \mathrm{c}$ & $1.76 \mathrm{a}$ & $1.82 \mathrm{a}$ & $1.52 \mathrm{~b}$ & 0.06 & 0.12 \\
\hline Leaf area duration (days) & $58.50 \mathrm{c}$ & $91.60 \mathrm{a}$ & $87.97 \mathrm{a}$ & $82.18 b$ & 2.37 & 4.79 \\
\hline Net assimilation rate $\left(\mathrm{g} \mathrm{m}^{-2}\right.$ day $\left.^{-1}\right)$ & $3.16 \mathrm{~d}$ & $5.10 \mathrm{a}$ & $4.76 b$ & $3.87 \mathrm{c}$ & 0.13 & 0.27 \\
\hline Crop growth rate $\left(\mathrm{g} \mathrm{m}^{-2} \mathrm{day}^{-1}\right)$ & $17.03 \mathrm{c}$ & $21.61 \mathrm{ab}$ & $22.24 \mathrm{a}$ & $20.95 b$ & 0.43 & 0.88 \\
\hline Weed control $(\%)$ & $0.0 \mathrm{~d}$ & $85.47 \mathrm{a}$ & $78.73 b$ & $69.33 c$ & 2.36 & 4.77 \\
\hline $\mathrm{N}(\%)$ & $2.22 \mathrm{c}$ & $3.71 \mathrm{a}$ & $3.56 \mathrm{ab}$ & $3.41 \mathrm{~b}$ & 0.15 & 0.20 \\
\hline $\mathrm{P}(\%)$ & $0.17 \mathrm{c}$ & $0.60 \mathrm{a}$ & $0.58 \mathrm{ab}$ & $0.54 \mathrm{~b}$ & 0.03 & 0.05 \\
\hline $\mathrm{K}(\%)$ & $1.32 \mathrm{~b}$ & $4.40 \mathrm{a}$ & $4.25 \mathrm{a}$ & $4.20 \mathrm{a}$ & 0.15 & 0.31 \\
\hline N-uptake $\left(\mathrm{kg} \mathrm{ha}^{-1}\right)$ & $73.25 c$ & $121.12 \mathrm{a}$ & $115.77 \mathrm{ab}$ & $110.42 b$ & 3.70 & 7.50 \\
\hline P-uptake $\left(\mathrm{kg} \mathrm{ha}^{-1}\right)$ & $8.24 \mathrm{c}$ & $21.48 \mathrm{a}$ & $19.48 \mathrm{~b}$ & $18.24 b$ & 0.79 & 1.61 \\
\hline K-uptake $\left(\mathrm{kg} \mathrm{ha}^{-1}\right)$ & $62.34 \mathrm{c}$ & $99.20 \mathrm{a}$ & $97.10 \mathrm{ab}$ & $92.28 \mathrm{~b}$ & 3.38 & 6.86 \\
\hline
\end{tabular}

Mean followed by common letters are not significantly 
The higher weed infestation enhanced weed crop competition for all limited resources including nutrients as evidenced by no weeding plot (W1) where wheat leaf $\mathrm{N}, \mathrm{P}$ and $\mathrm{K}$ concentration was reduced by 40.16, 72.0 and $70.0 \%$ over herbicide application (W2); 37.64, 70.9 and 68.94\% over hand hoeing (W3) and 35.0, 68.52 and $68.60 \%$ over allelopathic weed control (W4) respectively. Among the four weed management practices, weed control through herbicide application exhibited higher wheat leaf $\mathrm{N}(3.71 \%), \mathrm{P}(0.60 \%)$ and $\mathrm{K}$ concentration $(4.40 \%)$ followed by hand hoeing. Statistically, wheat leaf N and $\mathrm{P}$ concentration were at par when weeds were controlled by herbicide(W2) and by interculuring (W3) while K concentration was found non-significant at all weed management practices (i.e. W2, W3 and W4) (Table 3).

The interactive effect of fertilizer rates $\mathrm{x}$ weed management on wheat leaf $\mathrm{N}, \mathrm{P}$ and $\mathrm{K}$ concentration was differed significantly (Table 4). The non-significantly higher concentration of $\mathrm{N}, \mathrm{P}$ and $\mathrm{K}$ were exhibited by the interaction of fertilizer rates of 135-90-50 and 170-100-50 kg NPK ha ${ }^{-1}$ with weed management of W2, $\mathrm{W} 3$ and $\mathrm{W} 4$. While, the lower leaf $\mathrm{N}$ $(1.75 \%), \mathrm{P}(0.12 \%)$ and $\mathrm{K}$ concentration $(1.22 \%)$ were found at the interaction of zero fertilizer rate with W1 (no weeding). But, their minimum concentration of 1.58 , 0.18 and $1.28 \%$ was recorded at the interaction of 100-80-50 NPK kg ha- ${ }^{-1}$ W1 (no weeding).

\section{NPK uptake $\left(\mathrm{kg} \mathrm{ha}^{-1}\right)$ of wheat}

Wheat nutrients uptake varied significantly as affected by different fertilizer rates (Table 4). The LSD test for comparison of mean $(\mathrm{p}<0.05)$ displayed higher uptake of $\mathrm{N}\left(123.23 \mathrm{~kg} \mathrm{ha}^{-1}\right), \mathrm{P}\left(20.51 \mathrm{~kg} \mathrm{ha}^{-1}\right)$ and $\mathrm{K}$ $\left(109.81 \mathrm{~kg} \mathrm{ha}^{-1}\right)$ at fertilizer rate of 135 $90-50 \mathrm{~kg} \mathrm{ha}^{-1}$ followed by $113.69,20.44$ and $105.20 \mathrm{~kg} \mathrm{NPK} \mathrm{ha}^{-1}$ at the fertilizer rate of $170-100-50 \mathrm{~kg} \mathrm{ha}^{-1}$. While, minimum $\mathrm{N}, \mathrm{P}$ and $\mathrm{K}$ uptake $(83.15,6.83$ and $48.18 \mathrm{~kg} \mathrm{NPK} \mathrm{ha}^{-1}$ ) were observed at zero fertilizer rate. Statistically the uptake of $\mathrm{P}$ was at par at fertilizer rates of 135-9050, 170-100-50 and 205-110-50 kg NPK $\mathrm{ha}^{-1}$.

The presence of weeds in wheat crop increased weed crop competition that resulted in reduction of wheat nutrient uptake as evidenced by no weeding plot (W1) that resulted in reducing $\mathrm{N}, \mathrm{P}$ and $\mathrm{K}$ uptake of wheat by 39.52, 61.64 and $37.15 \%$ over chemical weed control (W2). Among them, chemical weed control exhibited higher $\mathrm{N}, \mathrm{P}$ and $\mathrm{K}$ uptake (121.12, 21.48 and $\left.99.20 \mathrm{~kg} \mathrm{ha}^{-1}\right)$ followed by $115.77,19.48$ and $97.10 \mathrm{~kg} \mathrm{NPK} \mathrm{ha}^{-1}$ at W3 (interculturing). The weed infestation as in no weedy plot (W1) indicated lower nutrients uptake of wheat crop (73.25, 8.24 and $62.34 \mathrm{~kg} \mathrm{NPK} \mathrm{ha}^{-1}$ ).

The interactive effect of fertilizer rates $\mathrm{x}$ weed management on $\mathrm{N}, \mathrm{P}$ and $\mathrm{K}$ uptake of wheat crop was significant as presented in (Table 4). The result showed higher uptake of N, P and K (143.46, 26.42 and $126.34 \mathrm{~kg} \mathrm{ha}^{-1}$ ) at the interactive effect of fertilizer rate (135-90-50 kg NPK ha' $\left.{ }^{-1}\right) \mathrm{x}$ W2 (herbicide application. While, the interaction between zero fertilizer rate and no weeding (W1) showed lower nutrient uptake of $59.85,5.33$ and $41.09 \mathrm{~kg}$ NPK $\mathrm{ha}^{-1}$. Non-significantly higher $\mathrm{P}$ uptake was observed at the interaction of higher fertilizer rates (135-90-50, 170-100-50 and 205-110-50 kg NPK ha-1) x W2. In case of $\mathrm{K}$ uptake, the interactive effect of higher fertilizer rates with $\mathrm{W} 2, \mathrm{~W} 3$ and $\mathrm{W} 4$ exhibited statistically at par differences but comparatively higher uptake while the interaction of zero fertilizer rate with weed management of $\mathrm{W} 2, \mathrm{~W} 3$ and $\mathrm{W} 4$ indicated at par lower $\mathrm{K}$ uptake as compared to other interactions (Table 4). 
Table 4. Plant traits as affected by the interactive effect of fertilizer rates $\mathbf{x}$ weed management practices

\begin{tabular}{|c|c|c|c|c|c|c|c|c|c|}
\hline \multirow{2}{*}{\multicolumn{2}{|c|}{$\begin{array}{l}\text { Fertilizer rates }(\mathrm{N}-\mathrm{P}-\mathrm{K}) \mathrm{x} \text { weed } \\
\text { management practices }\end{array}$}} & \multicolumn{8}{|c|}{ Plant traits } \\
\hline & & \multirow{2}{*}{$\begin{array}{c}\text { Plant height } \\
(\mathrm{cm})\end{array}$} & \multirow{2}{*}{$\frac{\text { Tillers }\left(\mathrm{m}^{-2}\right)}{149.33 \mathrm{n}}$} & \multirow{2}{*}{$\begin{array}{c}\begin{array}{c}\text { Spike length } \\
(\mathrm{cm})\end{array} \\
7.63 \mathrm{j}\end{array}$} & \multirow{2}{*}{$\begin{array}{c}\begin{array}{c}\text { Spikelets } \\
\text { spike }^{-1}\end{array} \\
14.67 \mathrm{k} \\
\end{array}$} & \multirow{2}{*}{$\begin{array}{c}\text { Grains spike }^{-1} \\
45.33 \mathrm{~h}\end{array}$} & \multirow{2}{*}{$\frac{\text { Seed index }(\mathrm{g})}{32.39 \mathrm{i}}$} & \multirow{2}{*}{$\begin{array}{c}\begin{array}{c}\text { Biological } \\
\text { yield }\left(\mathrm{t} \mathrm{ha}^{-1}\right)\end{array} \\
9.40 \mathrm{~g}\end{array}$} & \multirow{2}{*}{$\begin{array}{c}\begin{array}{c}\text { Grain yield } \\
\left(\mathrm{t} \mathrm{ha}^{-1}\right)\end{array} \\
1.85 \mathrm{j} \\
\end{array}$} \\
\hline \multirow{4}{*}{$0-0-0 \mathrm{~kg} \mathrm{ha}^{-1}$} & No weeding & & & & & & & & \\
\hline & Herbicideappl. & $75.77 \mathrm{klm}$ & $250.33 \mathrm{i}$ & $10.63 \mathrm{~g}$ & $24.00 \mathrm{f}-\mathrm{i}$ & $60.33 \mathrm{ef}$ & $35.14 \mathrm{fgh}$ & $9.83 \mathrm{~g}$ & $2.07 \mathrm{ij}$ \\
\hline & Hand pulling & $74.311 \mathrm{~m}$ & $237.0 \mathrm{ij}$ & $11.32 \mathrm{f}$ & $22.00 \mathrm{~g}-\mathrm{j}$ & 64.00de & $36.11 \mathrm{fg}$ & $9.6 \mathrm{~g}$ & $2.01 \mathrm{j}$ \\
\hline & $\begin{array}{l}\text { Allelopathic weed } \\
\text { management }\end{array}$ & $73.39 \mathrm{~m}$ & $247.0 \mathrm{i}$ & $9.83 \mathrm{~h}$ & $22.67 f-j$ & $58.67 f$ & $34.85 \mathrm{gh}$ & $10.47 f$ & $2.03 \mathrm{j}$ \\
\hline \multirow{4}{*}{$100-80-50 \mathrm{~kg} \mathrm{ha}^{-1}$} & No weeding & $77.13 \mathrm{jkl}$ & $174.671 \mathrm{~m}$ & $8.23 \mathrm{i}$ & $19.33 \mathrm{j}$ & $45.33 \mathrm{~h}$ & $34.90 \mathrm{gh}$ & $10.63 \mathrm{ef}$ & $2.31 \mathrm{hi}$ \\
\hline & Herbicide appl. & $85.22 \mathrm{efg}$ & $371.67 \mathrm{~h}$ & $12.27 \mathrm{~cd}$ & $26.67 c-f$ & $73.00 \mathrm{c}$ & $41.37 \mathrm{~b}$ & $11.40 \mathrm{c}$ & $4.20 \mathrm{c}$ \\
\hline & Hand pulling & $83.34 \mathrm{gh}$ & $403.67 \mathrm{~g}$ & $12.17 \mathrm{~d}$ & $28.67 \mathrm{~b}-\mathrm{e}$ & $73.00 \mathrm{c}$ & $41.07 \mathrm{~b}$ & $10.73 \mathrm{def}$ & $3.85 \mathrm{de}$ \\
\hline & $\begin{array}{c}\text { Allelopathic weed } \\
\text { management }\end{array}$ & 81.23hi & $378.00 \mathrm{~h}$ & $12.17 \mathrm{~d}$ & $26.67 \mathrm{c}-\mathrm{f}$ & $73.00 \mathrm{c}$ & $38.39 \mathrm{~cd}$ & $10.87 \mathrm{c}-\mathrm{f}$ & $3.70 \mathrm{e}$ \\
\hline \multirow{4}{*}{$135-90-50 \mathrm{~kg} \mathrm{ha}^{-1}$} & No weeding & $78.38 \mathrm{ijk}$ & $219.0 \mathrm{jk}$ & $9.43 \mathrm{~h}$ & 21.00hij & $58.67 \mathrm{f}$ & 37.69de & $10.47 \mathrm{f}$ & $3.01 \mathrm{f}$ \\
\hline & Herbicide appl. & $88.61 \mathrm{a}-\mathrm{d}$ & 511.67 & $13.03 \mathrm{ab}$ & $31.33 \mathrm{ab}$ & $86.00 \mathrm{a}$ & $44.72 \mathrm{a}$ & $12.40 \mathrm{~b}$ & $5.18 \mathrm{a}$ \\
\hline & Hand pulling & $86.85 c-f$ & $545.0 \mathrm{a}$ & $13.13 \mathrm{a}$ & $33.67 \mathrm{a}$ & $89.67 \mathrm{a}$ & $44.43 a$ & $12.23 \mathrm{~b}$ & $5.12 \mathrm{a}$ \\
\hline & $\begin{array}{c}\text { Allelopathic weed } \\
\text { management }\end{array}$ & $84.3 f g$ & $474.33 \mathrm{~cd}$ & $12.87 \mathrm{ab}$ & $30.33 \mathrm{abc}$ & $79.00 \mathrm{~b}$ & $41.36 b$ & $12.23 b$ & $4.73 b$ \\
\hline \multirow{4}{*}{$170-100-50 \mathrm{~kg} \mathrm{ha}^{-1}$} & No weeding & $80.07 \mathrm{ij}$ & $196.67 \mathrm{kl}$ & $8.63 \mathrm{i}$ & $20.33 \mathrm{ij}$ & $51.33 \mathrm{~g}$ & $35.76 f g$ & $11.03 \mathrm{cde}$ & $2.66 \mathrm{~g}$ \\
\hline & Herbicide appl. & $90.02 \mathrm{ab}$ & $468.33 \mathrm{~cd}$ & $12.63 b c$ & $29.67 a-d$ & $79.00 \mathrm{~b}$ & $43.98 \mathrm{a}$ & $13.10 \mathrm{a}$ & $4.78 \mathrm{~b}$ \\
\hline & Hand pulling & $87.98 \mathrm{~b}-\mathrm{e}$ & $488.33 c$ & $12.63 b c$ & $28.67 b-e$ & $79.00 \mathrm{~b}$ & $43.52 \mathrm{a}$ & $12.37 \mathrm{~b}$ & $4.65 b$ \\
\hline & $\begin{array}{c}\text { Allelopathic weed } \\
\text { management }\end{array}$ & $85.78 \mathrm{~d}-\mathrm{g}$ & 439.0ef & $12.34 \mathrm{~cd}$ & $29.00 \mathrm{~b}-\mathrm{e}$ & $73.00 \mathrm{c}$ & $40.86 \mathrm{~b}$ & $13.00 \mathrm{a}$ & $4.16 \mathrm{c}$ \\
\hline \multirow{4}{*}{$205-110-50$} & No weeding & $80.28 \mathrm{i}$ & $160.0 \mathrm{mn}$ & $11.03 \mathrm{fg}$ & $23.33 \mathrm{f}-\mathrm{j}$ & 64.00de & 33.82hi & $11.23 \mathrm{c}$ & $2.51 \mathrm{gh}$ \\
\hline & Herbicideappl. & $91.25 \mathrm{a}$ & $428.67 \mathrm{f}$ & $11.43 \mathrm{ef}$ & $25.33 \mathrm{~d}-\mathrm{h}$ & 64.00de & $39.28 \mathrm{c}$ & $13.30 \mathrm{a}$ & $4.34 \mathrm{c}$ \\
\hline & Hand pulling & $89.61 \mathrm{abc}$ & $455.67 \mathrm{de}$ & $11.73 \mathrm{e}$ & $26.00 \mathrm{c}-\mathrm{g}$ & $67.67 \mathrm{~d}$ & $38.76 \mathrm{~cd}$ & $13.10 \mathrm{a}$ & $4.10 \mathrm{~cd}$ \\
\hline & $\begin{array}{c}\text { Allelopathic weed } \\
\text { management }\end{array}$ & 86.39def & $417.33 \mathrm{fg}$ & $11.23 \mathrm{f}$ & $24.67 \mathrm{e}-\mathrm{i}$ & 64.00de & $36.47 \mathrm{ef}$ & $13.23 \mathrm{a}$ & $3.80 \mathrm{e}$ \\
\hline S.E. & & 1.48 & 11.41 & 0.20 & 2.26 & 1.99 & 0.75 & 0.28 & 0.13 \\
\hline LSD at 0.05 & & 3.01 & 23.11 & 0.41 & 4.57 & 4.02 & 1.51 & 0.56 & 0.26 \\
\hline
\end{tabular}




\begin{tabular}{|c|c|c|c|c|c|c|c|}
\hline \multirow{2}{*}{\multicolumn{2}{|c|}{ Fertilizer rates $(\mathrm{N}-\mathrm{P}-\mathrm{K}) \mathrm{x}$ weed management practices }} & \multicolumn{6}{|c|}{ Plant traits } \\
\hline & & \multirow{2}{*}{$\begin{array}{c}\text { Harvest index } \\
(\%)\end{array}$} & \multirow{2}{*}{$\begin{array}{c}\begin{array}{c}\text { Leaf area }\left(\mathrm{cm}^{2}\right. \\
\left.\text { plant }^{-1}\right)\end{array} \\
215.10 \mathrm{j}\end{array}$} & \multirow{2}{*}{$\begin{array}{c}\text { Leaf area index } \\
0.38 \mathrm{k}\end{array}$} & \multirow{2}{*}{$\frac{\text { LAD (days) }}{44.13 \mathrm{i}}$} & \multirow{2}{*}{$\begin{array}{c}\text { NAR } \\
\left(\mathrm{g} \mathrm{m}^{-2} \mathrm{day}^{-1}\right)\end{array}$} & \multirow{2}{*}{$\begin{array}{c}\begin{array}{c}\text { CGR } \\
\left(\mathrm{g} \mathrm{m}^{-2} \mathrm{day}^{-1}\right)\end{array} \\
15.351 \\
\end{array}$} \\
\hline \multirow{4}{*}{$0-0-0 \mathrm{~kg} \mathrm{ha}^{-1}$} & No weeding & & & & & & \\
\hline & Herbicideappl. & $21.03 \mathrm{ij}$ & $247.17 \mathrm{hi}$ & $0.71 \mathrm{ij}$ & $46.81 \mathrm{hi}$ & $3.57 \mathrm{ghi}$ & $18.55 \mathrm{~h}-\mathrm{k}$ \\
\hline & Hand pulling & $20.90 \mathrm{ijk}$ & $279.47 \mathrm{~g}$ & $1.02 \mathrm{~h}$ & 52.60ghi & 3.33hij & 18.89hij \\
\hline & Allelopathic weed management & $19.30 \mathrm{k}$ & $245.57 \mathrm{~g}$ & $0.78 \mathrm{hi}$ & $52.16 \mathrm{ghi}$ & $3.20 \mathrm{ijk}$ & $17.75 \mathrm{ijk}$ \\
\hline \multirow{4}{*}{$100-80-50 \mathrm{~kg} \mathrm{ha}^{-1}$} & No weeding & $21.67 \mathrm{i}$ & $227.40 \mathrm{ij}$ & $0.45 \mathrm{jk}$ & $56.53 \mathrm{gh}$ & $3.17 \mathrm{ijk}$ & $16.59 \mathrm{kl}$ \\
\hline & Herbicideappl. & $36.77 \mathrm{~cd}$ & $301.00 \mathrm{~d}-\mathrm{g}$ & $1.59 \mathrm{efg}$ & $94.36 \mathrm{cde}$ & $5.30 \mathrm{bc}$ & $21.78 \mathrm{def}$ \\
\hline & Hand pulling & $35.87 \mathrm{~d}$ & $298.43 \mathrm{~d}-\mathrm{g}$ & $1.56 \mathrm{fg}$ & $87.60 \mathrm{de}$ & $4.97 \mathrm{~cd}$ & $22.89 b-e$ \\
\hline & Allelopathic weed management & $34.03 \mathrm{e}$ & $282.50 \mathrm{fg}$ & $1.36 \mathrm{~g}$ & 85.40de & $3.93 \mathrm{e}-\mathrm{h}$ & $21.26 \mathrm{efg}$ \\
\hline \multirow{4}{*}{$135-90-50 \mathrm{~kg} \mathrm{ha}^{-1}$} & No weeding & $28.87 \mathrm{~g}$ & 232.67hij & $0.49 \mathrm{jk}$ & $71.10 \mathrm{f}$ & $3.73 \mathrm{f}-\mathrm{i}$ & $17.33 \mathrm{jk}$ \\
\hline & Herbicideappl. & $41.80 \mathrm{a}$ & $309.80 \mathrm{cde}$ & $1.94 \mathrm{bcd}$ & $118.22 \mathrm{a}$ & $6.200 \mathrm{a}$ & $24.72 \mathrm{ab}$ \\
\hline & Hand pulling & $41.83 \mathrm{a}$ & 304.40def & $1.85 \mathrm{cde}$ & $109.33 \mathrm{ab}$ & $5.80 \mathrm{ab}$ & $25.38 \mathrm{a}$ \\
\hline & Allelopathic weed management & $38.63 b$ & $290.77 \mathrm{efg}$ & $1.58 \mathrm{efg}$ & $103.07 \mathrm{bc}$ & $4.50 \mathrm{de}$ & $24.15 \mathrm{abc}$ \\
\hline \multirow{4}{*}{$170-100-50 \mathrm{~kg} \mathrm{ha}^{-1}$} & No weeding & $24.13 \mathrm{~h}$ & $245.57 \mathrm{hi}$ & $0.62 \mathrm{ijk}$ & $59.77 \mathrm{~g}$ & 3.50ghi & $17.75 \mathrm{ijk}$ \\
\hline & Herbicideappl. & $36.50 \mathrm{~cd}$ & $319.07 \mathrm{bcd}$ & $2.13 \mathrm{~b}$ & $103.53 \mathrm{bc}$ & $6.03 \mathrm{a}$ & $23.33 \mathrm{bcd}$ \\
\hline & Hand pulling & $37.60 \mathrm{bc}$ & $311.03 \mathrm{cde}$ & $2.03 \mathrm{bcd}$ & $100.87 \mathrm{bc}$ & $5.70 \mathrm{ab}$ & $23.87 \mathrm{abc}$ \\
\hline & Allelopathic weed management & $31.90 \mathrm{f}$ & 304.77def & 1.79 def & $86.53 \mathrm{de}$ & $4.20 \mathrm{ef}$ & $22.27 \mathrm{cde}$ \\
\hline \multirow{4}{*}{$205-110-50 \mathrm{~kg} \mathrm{ha}^{-1}$} & No weeding & $22.33 \mathrm{i}$ & $248.73 \mathrm{hi}$ & $0.68 \mathrm{ij}$ & $60.98 \mathrm{fg}$ & $2.81 \mathrm{jk}$ & $18.11 \mathrm{ijk}$ \\
\hline & Herbicideappl. & $32.57 \mathrm{ef}$ & $337.17 \mathrm{ab}$ & $2.41 \mathrm{a}$ & $95.08 \mathrm{~cd}$ & $4.33 \mathrm{ef}$ & 19.64ghi \\
\hline & Hand pulling & $31.20 \mathrm{f}$ & $352.30 \mathrm{a}$ & $2.63 \mathrm{a}$ & $89.45 \mathrm{de}$ & 4.01efg & $20.18 \mathrm{fgh}$ \\
\hline & Allelopathic weed management & $28.70 \mathrm{~g}$ & $329.50 \mathrm{bc}$ & $2.11 \mathrm{bc}$ & $83.74 \mathrm{e}$ & 3.50ghi & $19.29 \mathrm{hij}$ \\
\hline \multicolumn{2}{|r|}{ S.E. } & 0.85 & 11.38 & 0.14 & 5.29 & 0.29 & 0.97 \\
\hline \multicolumn{2}{|c|}{ LSD at 0.05} & 1.72 & 22.54 & 0.28 & 10.71 & 0.61 & 1.97 \\
\hline
\end{tabular}




\begin{tabular}{|c|c|c|c|c|c|c|c|c|}
\hline \multirow{3}{*}{\multicolumn{2}{|c|}{$\begin{array}{c}\text { Fertilizer rates (N-P-K) x weed management } \\
\text { practicens }\end{array}$}} & \multicolumn{7}{|c|}{ Plant traits } \\
\hline & & \multirow{2}{*}{$\begin{array}{c}\text { Weed control } \\
(\%)\end{array}$} & \multicolumn{3}{|c|}{ Wheat leaf nutrient concentration $(\%)$} & \multicolumn{3}{|c|}{ Wheat nutrient uptake $\left(\mathrm{kg} \mathrm{ha}^{1}\right)$} \\
\hline & & & $\mathrm{N}$ & $\mathrm{P}$ & $\mathrm{K}$ & $\mathrm{N}$ & $\mathrm{P}$ & $\mathrm{K}$ \\
\hline \multirow{4}{*}{$0-0-0 \mathrm{~kg} \mathrm{ha}^{-1}$} & No weeding & $0.00 \mathrm{c}$ & $1.75 \mathrm{~h}$ & $0.12 \mathrm{j}$ & $1.22 \mathrm{i}$ & $59.85 \mathrm{k}$ & $5.33 \mathrm{f}$ & $41.09 \mathrm{~g}$ \\
\hline & Herbicideappl. & $85.00 \mathrm{a}$ & $2.71 d-g$ & $0.27 \mathrm{ghi}$ & $3.63 \mathrm{fgh}$ & 88.54ghi & $8.01 \mathrm{ef}$ & $51.84 \mathrm{fg}$ \\
\hline & Hand pulling & $78.67 \mathrm{ab}$ & $2.78 \mathrm{def}$ & $0.30 \mathrm{~g}$ & $3.50 \mathrm{gh}$ & $99.13 \mathrm{fgh}$ & $6.95 \mathrm{ef}$ & $49.14 \mathrm{fg}$ \\
\hline & $\begin{array}{c}\text { Allelopathic weed } \\
\text { management }\end{array}$ & $69.00 \mathrm{~b}$ & $2.71 \mathrm{~d}-\mathrm{g}$ & $0.28 \mathrm{gh}$ & $3.36 \mathrm{~h}$ & 85.10hij & $7.04 \mathrm{ef}$ & $50.65 f g$ \\
\hline \multirow{4}{*}{$100-80-50 \mathrm{~kg} \mathrm{ha}^{-1}$} & No weeding & $0.00 \mathrm{c}$ & $2.10 \mathrm{gh}$ & $0.16 \mathrm{ij}$ & $1.33 \mathrm{i}$ & $69.13 \mathrm{jk}$ & 7.84ef & $58.00 \mathrm{ef}$ \\
\hline & Herbicideappl. & $85.0 \mathrm{a}$ & $3.33 \mathrm{~cd}$ & $0.50 \mathrm{def}$ & $4.08 \mathrm{~d}-\mathrm{g}$ & $112.33 \mathrm{def}$ & $20.36 \mathrm{bcd}$ & $83.88 \mathrm{c}$ \\
\hline & Hand pulling & $79.00 \mathrm{ab}$ & $3.09 \mathrm{cde}$ & $0.43 \mathrm{f}$ & $3.91 \mathrm{e}-\mathrm{h}$ & $108.77 \mathrm{def}$ & $18.83 \mathrm{~cd}$ & $82.52 \mathrm{~cd}$ \\
\hline & $\begin{array}{l}\text { Allelopathic weed } \\
\text { management }\end{array}$ & $69.00 \mathrm{~b}$ & $3.24 \mathrm{~cd}$ & $0.48 \mathrm{ef}$ & $4.22 \mathrm{c}-\mathrm{f}$ & $104.27 \mathrm{efg}$ & $17.57 \mathrm{~d}$ & $75.92 \mathrm{~cd}$ \\
\hline \multirow{4}{*}{$135-90-50 \mathrm{~kg} \mathrm{ha}^{-1}$} & No weeding & $0.00 \mathrm{c}$ & $2.39 \mathrm{fgh}$ & $0.22 \mathrm{~g}-\mathrm{j}$ & $1.38 \mathrm{i}$ & $81.88 \mathrm{ij}$ & $9.40 \mathrm{e}$ & $72.33 \mathrm{cde}$ \\
\hline & Herbicideappl. & $85.67 \mathrm{a}$ & $4.47 \mathrm{a}$ & $0.78 \mathrm{a}$ & $5.0 \mathrm{ab}$ & $143.46 \mathrm{a}$ & $26.42 \mathrm{a}$ & $126.34 \mathrm{a}$ \\
\hline & Hand pulling & $87.67 \mathrm{ab}$ & $4.22 \mathrm{ab}$ & $0.81 \mathrm{a}$ & $4.75 a-d$ & $134.93 \mathrm{abc}$ & $23.94 \mathrm{ab}$ & $124.20 \mathrm{a}$ \\
\hline & $\begin{array}{l}\text { Allelopathic weed } \\
\text { management }\end{array}$ & $69.33 b$ & $4.57 \mathrm{a}$ & $0.74 \mathrm{a}$ & $5.10 \mathrm{a}$ & $132.66 \mathrm{abc}$ & $22.30 \mathrm{bc}$ & $116.37 \mathrm{ab}$ \\
\hline \multirow{4}{*}{$170-100-50 \mathrm{~kg} \mathrm{ha}^{-1}$} & No weeding & $0.00 \mathrm{c}$ & $2.54 \mathrm{efg}$ & 0.18hij & $1.36 \mathrm{i}$ & $77.70 \mathrm{ij}$ & $9.33 \mathrm{e}$ & $72.76 \mathrm{cde}$ \\
\hline & Herbicideappl. & $86.00 \mathrm{a}$ & $4.52 \mathrm{a}$ & $0.76 \mathrm{a}$ & $4.98 \mathrm{ab}$ & $136.63 \mathrm{ab}$ & $26.34 \mathrm{a}$ & $119.48 \mathrm{ab}$ \\
\hline & Hand pulling & $78.66 \mathrm{ab}$ & $4.32 \mathrm{ab}$ & $0.70 \mathrm{ab}$ & $4.87 \mathrm{abc}$ & $122.08 \mathrm{bcd}$ & $23.87 \mathrm{ab}$ & $116.79 \mathrm{ab}$ \\
\hline & $\begin{array}{l}\text { Allelopathic weed } \\
\text { management }\end{array}$ & $69.67 \mathrm{~b}$ & $3.72 b c$ & $0.61 \mathrm{bcd}$ & $4.47 \mathrm{a}-\mathrm{e}$ & $118.37 \mathrm{cde}$ & $22.25 b c$ & $111.78 \mathrm{ab}$ \\
\hline \multirow{4}{*}{$205-110-50 \mathrm{~kg} \mathrm{ha}^{-1}$} & No weeding & $0.00 \mathrm{c}$ & $2.34 \mathrm{fgh}$ & 0.18hij & $1.31 \mathrm{i}$ & $77.68 \mathrm{ij}$ & $9.32 \mathrm{e}$ & $67.54 \mathrm{de}$ \\
\hline & Herbicideappl. & $85.66 \mathrm{a}$ & $3.54 \mathrm{c}$ & $0.70 \mathrm{ab}$ & $4.33 \mathrm{~b}-\mathrm{e}$ & $124.62 \mathrm{bcd}$ & $26.28 \mathrm{a}$ & $114.48 \mathrm{ab}$ \\
\hline & Hand pulling & $78.66 \mathrm{ab}$ & $3.37 \mathrm{~cd}$ & $0.63 \mathrm{bc}$ & $4.23 c-f$ & $113.96 \mathrm{def}$ & $23.85 \mathrm{ab}$ & $112.72 \mathrm{ab}$ \\
\hline & $\begin{array}{l}\text { Allelopathic weed } \\
\text { management }\end{array}$ & $69.67 \mathrm{~b}$ & $2.83 \mathrm{def}$ & $0.57 \mathrm{cde}$ & $3.88 \mathrm{e}-\mathrm{h}$ & $111.73 \mathrm{def}$ & $22.04 b c$ & $106.69 b$ \\
\hline \multicolumn{2}{|c|}{ S.E. } & 5.27 & 0.33 & 0.06 & 0.34 & 8.28 & 1.78 & 7.57 \\
\hline \multicolumn{2}{|c|}{ LSD at 0.05} & 10.67 & 0.67 & 0.12 & 0.68 & 16.77 & 3.61 & 15.33 \\
\hline
\end{tabular}




\section{Correlations}

The extent of relationship as depicted in (Figure $1 \mathrm{a} \& \mathrm{~b}$ and Figure 2a-f) showed that wheat grain yield had positive relationship with LAD $(r=0.97)$, NAR $(\mathrm{r}=0.88)$, leaf area index $(\mathrm{r}=0.93)$, tillers $\mathrm{m}^{-2}(\mathrm{r}=0.94)$ and harvest index $(\mathrm{r}=0.96)$, and according to (Figure 2d, e \& f) there was positive relationship between biological yield and plant height $(\mathrm{r}=0.84)$, leaf area index and leaf area $(\mathrm{r}=0.95)$ as well as LAD and leaf area $(r=0.87)$.

The variation in wheat grain yield was due to its association with LAD (94\%), NAR (77 $\%)$, LAI $(86 \%)$, tillers $\mathrm{m}^{-2}(88 \%)$ and harvest index (93). Likewise, Variation in biological yield was due to its association with plant height $(71 \%)$. The change in leaf area index was due to its connection with leaf area (89\%), variation in LAD was due to its coalition with leaf area (76\%).

Unit increase in various yield components of wheat correspondingly enhanced grain yield

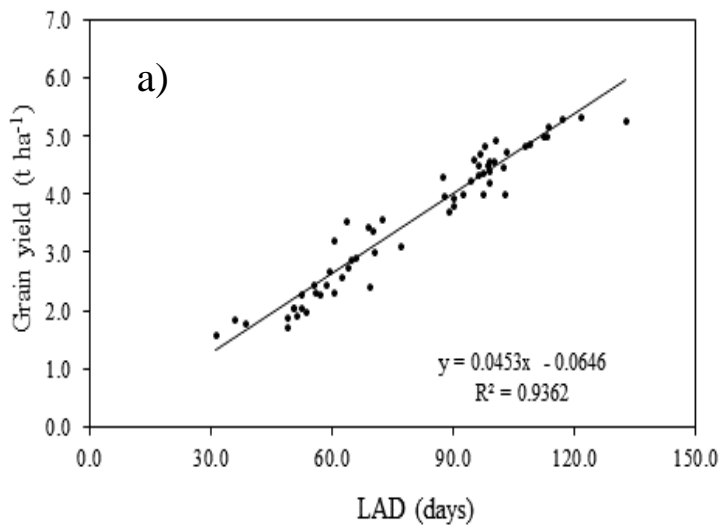

by LAD $\left(0.05 \mathrm{t} \mathrm{ha}^{-1}\right)$, NAR $\left(0.14 \mathrm{t} \mathrm{ha}^{-1}\right)$, LAI $\left(1.45 \mathrm{t} \mathrm{ha}^{-1}\right)$, tillers $\mathrm{m}^{-2}\left(0.01 \mathrm{t} \mathrm{ha}^{-1}\right)$ and harvest index $\left(0.14 \mathrm{t} \mathrm{ha}^{-1}\right)$ While, a unit increase in plant height resulted in correspondingly increased biological yield by $0.16 \mathrm{t} \mathrm{ha}^{-1}$, whereas, a unit increase in LA improved LAI by 0.02 and LAD by 0.47 days.

The student Test was performed on those growth parameters of wheat which had showed correlations and the calculated $\mathrm{T}$ value was examined for grain yield vs LAI (18.67), grain yield vs tillers (20.45), grain yield vs harvest index (27.44), grain yield vs LAD (29.32), grain yield with NAR (13.79), biological yield vs plant height (11.90), LAI vs LA (22.17) and LAD vs LA (13.38). These $\mathrm{T}$ values were found higher than book value as calculated at $5 \%$ probability level which indicate that the correlations are highly significant.

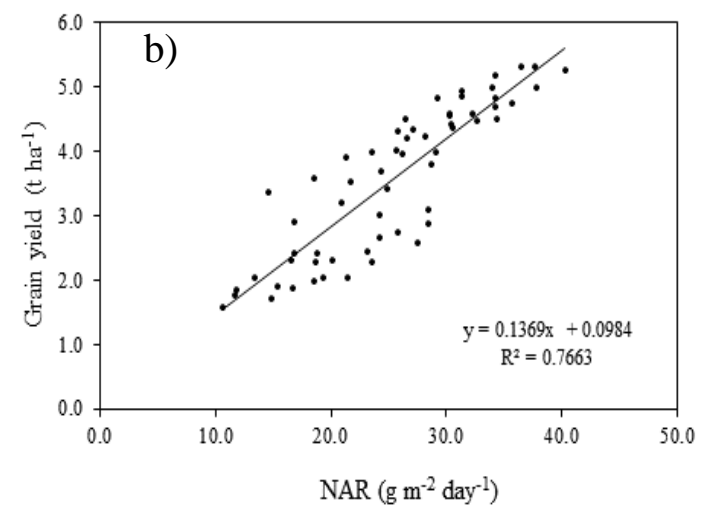

Figure 1. Linear regression between wheat grain yield and LAD (a) and NAR (b) as affected by NPK fertilizer and weed management practices 

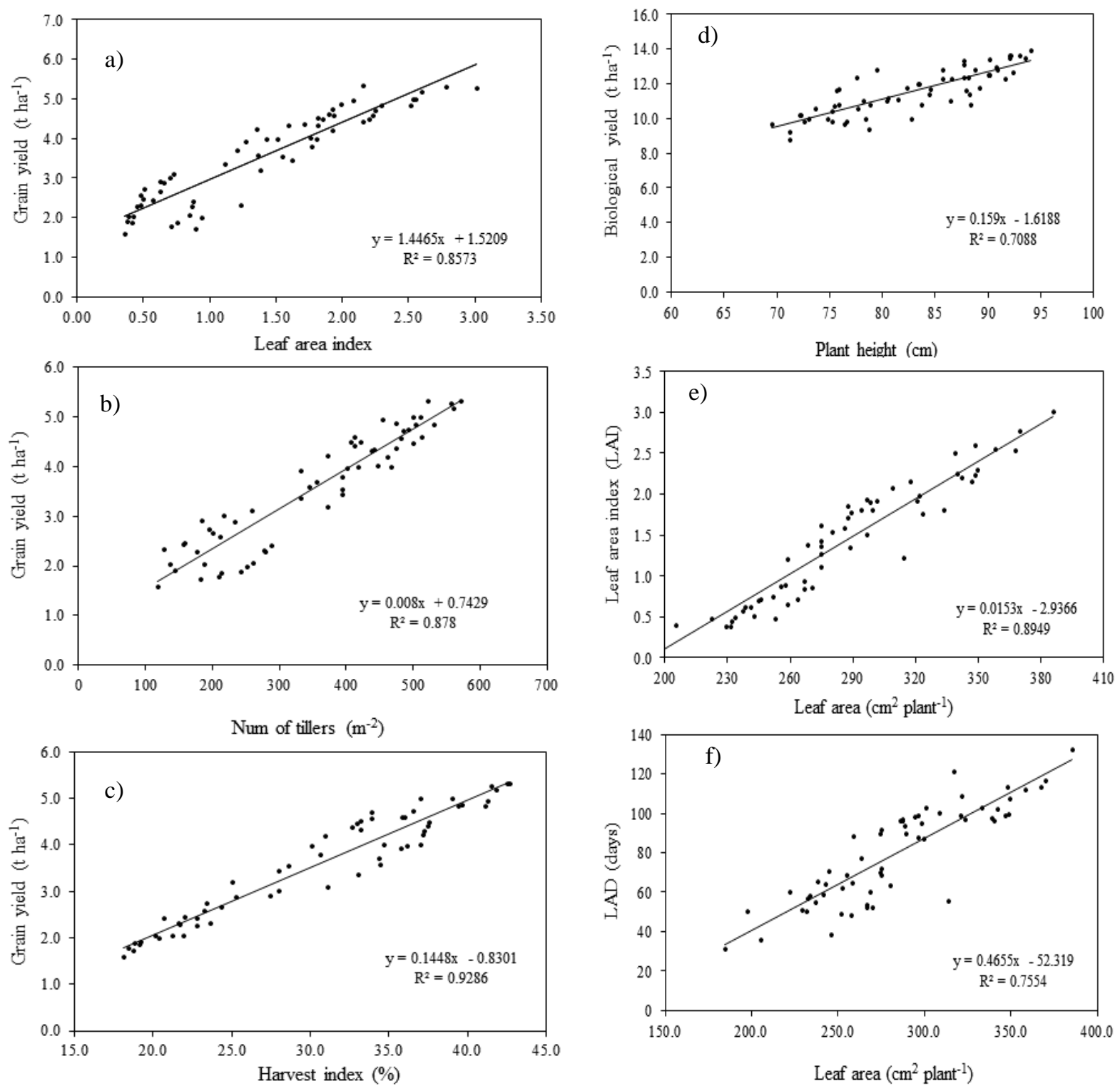

Figure 2. Linear regression between grain yield and LAI (a), grain yield and number of tillers $\mathrm{m}^{-2}$ (b) and grain yield and harvest index (c), while biological yield and plant height (d), leaf area and leaf area index (e) as well as LAD and leaf area (f) as affected by NPK fertilizer and weed management practices

\section{Discussion}

The results regarding agronomic characteristics of wheat such as plant height, tillers per unit area, spike length, spikelets spike $^{-1}$, grains spike ${ }^{-1}$, seed index, biological yield, grain yield and harvest index, while the physiological traits like leaf area, leaf index, leaf area duration, net assimilation rate and crop growth rate as well as wheat leaf nutrient concentration ( $\mathrm{N}, \mathrm{P}$ and $\mathrm{K} \%$ ) and nutrient uptake ( $\mathrm{N}, \mathrm{P}$ and $\mathrm{K} \mathrm{kg} \mathrm{ha}{ }^{-1}$ ) were significantly affected by fertilizer rates, weed management practices and their interaction.

As regard to the effect of NPK fertilizer rates on agronomic characteristics of wheat, the higher fertilizer rate of $205-110-50 \mathrm{~kg}$ NPK ha ${ }^{-1}$ displayed higher plant height and 
biological yield and minimum values were presented in control plot. While, the medium fertilizer rate of 135-90-50 kg NPK ha ${ }^{-1}$ showed maximum tillers $\mathrm{m}^{-2}$, spike length, spikelets spike $^{-1}$, grain spike ${ }^{-1}$, seed index, grain yield and harvest index. It means that increasing fertilizer rates particularly $\mathrm{N}$ have increased vegetative growth and reduced reproductive growth as observed in higher biological yield that might be due to higher plant height. The other reason of lower reproductive growth at this higher fertilizer rates is might be due to higher weed density and weed biomass which competed more for light and nutrients than wheat crop. The higher grain yield on medium fertilizer rate is due to improvement in yield components like tillers $\mathrm{m}^{-2}$, spike length, spikelets spike 1, grains spike ${ }^{-1}$, seed index and harvest index. Such association of yield and its components can be mirrored from linear regression analysis which revealed that grain yield was positively and significantly correlated with LAI, tillers $\mathrm{m}^{-2}$, harvest index and NAR. Together with that some positive and significant correlation were also existed between biological yield vs plant height, LAI vs LA and LAD vs LA. These results are supported by Chauhan [7] who revealed that fertilizer rate of 120-60-40 NPK $\mathrm{kg} \mathrm{ha}^{-1}$ increased the growth characteristics of wheat as compared to control where no fertilizer was applied. At this fertilizer rate maximum plant height of $92.4 \mathrm{~cm}$ was recorded that might be due to increased meristematic activity resulting in plant height enhancement. There was $33.3 \%$ higher grain yield and 35\% straw yield over control plot. The higher fertilizer rates exhibited maximum biological yield which might be attributed to increased plant height. All the studied physiological characteristics of wheat were observed higher at the medium fertilizer rate of 135-90-50 kg NPK $\mathrm{ha}^{-1}$ followed by the fertilizer rate of 170 100-50 kg NPK ha-1 ${ }^{-1}$ The higher fertilizer rate resulted in reduction of these physiological traits. However, their lowest values were noted in control plot. In this study, the higher wheat leaf $\mathrm{N}, \mathrm{P}$ and $\mathrm{K}$ concentration and their uptake were recorded at the medium fertilizer rates of 135-90-50 and 170-100-50 kg NPK ha ${ }^{-1}$. But the higher fertilizer rates resulted in reduction of nutrients concentration and uptake which might be due higher weed infestation as well as growth dilution effect. While control plot (zero fertilization) showed lower leaf $\mathrm{N}$ and $\mathrm{K}$ concentration as well as lower N, P and K uptake. Kalsoom et al. [47] reported that crop growth and dry matter is increased by the combined application of NPK rather than their alone application. Similar beneficial effect of chemical fertilizer on wheat was also observed by Sandhya et al. [48].

The wheat physiological characteristics such as leaf area, LAI, LAD, NAR and CGR were significantly affected by weed management practices. The maximum leaf area $\left(\mathrm{cm}^{2}\right.$ plant $\left.{ }^{-1}\right)$, leaf area index, LAD (days), NAR $\left(\mathrm{g} \mathrm{m}^{-2} \mathrm{day}^{-1}\right)$ and CGR $\left(\mathrm{g} \mathrm{m}^{-2}\right.$ day $^{-1}$ ) were examined in plot when weed were controlled by herbicides application with closely followed by hand pulling method of weed control. As compared to no weeding, the allelopathic weed control also resulted in increasing physiological traits of wheat but were less effective as compared to herbicides application and hand pulling weed control. This increase in physiological traits might be due to reduction of competition between wheat and weeds for space, moisture, nutrients and light because weeds are one of the important constraints for sustainable yield production of most crops particularly of wheat. Similar effect of weeds control on wheat physiological characteristics were reported by Mubeen et al. [49] who observed maximum leaf area index and leaf area duration of rice in chemically weed control plot (penoxsulam 
or bispyribac-sodium) followed by handhoeing. Similarly, Iqbal and Wright [50] reported that increasing weed density resulted in lower wheat net assimilation rate. The effects of weed infestation on rice growth indices such as LAI, CGR and LAD were studied by Ashraf et al. [51]. They recorded higher LAI, CGR and LAD of rice crop in weed free plot while weed infestation resulted in reduction of these growth indices of rice. Same results were also reported by Islam et al. [52] who observed maximum CGR of crop when there was less crop weed competition and where resources were adequate. Girma [53] revealed that LAI and CGR were decreased by $61-75 \%$ due to competition of wild mustard. Similar results were reported by Fischer [54] who indicated that a decrease in CGR of wheat related with a simultaneous decline in light interception.

As regard to the interactive effect of fertilizer rates $\mathrm{x}$ weed management practices, the result revealed significantly higher plant height in the interactive effect of fertilizer rate of 205-110-50 kg NPK ha-1 $\mathrm{x}$ weed control by herbicides application while higher biological yield was noted at same fertilizer with three weed management of W2, W3 and W4. The other agronomic traits like tillers $\mathrm{m}^{-2}$, spike length, spikelets spike $^{-1}$, grains spike ${ }^{-1}$, seed index, grain yield and harvest index manifested higher values at the interaction of fertilizer rate (135-90-50 kg NPK ha-1) x W2 and W3. In contrast, the weed infested plot (control) with and without fertilizer application suppressed all these traits. Similar interaction was reported by Pourreza et al. [55] who examined significant effect of wild oat densities, $\mathrm{N}$ rates and the interaction of wild oat density $\mathrm{x} N$ rates on wheat grain yield. They found maximum $\left(400.3 \mathrm{~g} \mathrm{~m}^{-2}\right)$ wheat grain yield at the interactive effect of $\mathrm{N}$ rate $\left(50 \mathrm{~N} \mathrm{~kg} \mathrm{ha}^{-1}\right.$ pre-sowing time +100 $\mathrm{N} \mathrm{kg} \mathrm{ha}{ }^{-1}$ at late tillering) $\mathrm{x}$ zero wild oat density. The interactive effect of higher $\mathrm{N}$ rate $\left(150 \mathrm{~N} \mathrm{~kg} \mathrm{ha}^{-1}\right.$ at pre seeding) $\mathrm{x}$ higher wild oat density (100 seeds $\mathrm{m}^{-2}$ ) produced lower $\left(173.3 \mathrm{~g} \mathrm{~m}^{-2}\right)$ wheat grain yield. These results are in accordance with Sary et al. [56] who noted that the interactive effect of herbicides application $\mathrm{x}$ fertilizer rate $(25 \%$ bio-organic and $75 \%$ recommended NPK) had good impact on reduction of weeds at 75 days after sowing. But after 105 DAS, the interactive of herbicide application x 100\% recommended NPK was most effective against weeds. They revealed that the interactive effect of herbicide application $\mathrm{x}$ recommended NPK fertilizer produced higher number of tillers $\mathrm{m}^{-2}$, number of spikes $\mathrm{m}^{-2}$, biological and grain yield.

As regard to the interactive effect of fertilizer rate $\mathrm{x}$ weed management, the higher $\mathrm{N}, \mathrm{P}$ and $\mathrm{K}$ concentration and uptake was recorded in the interaction of medium fertilizer rate of $135-90-50 \mathrm{~kg} \mathrm{NPK} \mathrm{ha}{ }^{-1}$ with $\mathrm{W} 2, \mathrm{~W} 3$ and W4 while, weed infested plot (weedy check) resulted in reduced wheat leaf N, P and K concentration and uptake on all fertilizer rates. Similar results were reported by Sary et al. [56] who recorded higher $\mathrm{P}$ and $\mathrm{K}$ uptake of wheat at the interactive effect of hand weeding $\mathrm{X}$ fertilizer rate $(25 \%$ recommended bioorganic fertilizer $+75 \%$ recommended NPK fertilizer). Similar results were observed by Singh [57] that NPK application and weed control by Pendimethalin manifested useful impact on overall growth of wheat and increased grain yield.

\section{Conclusion}

From this study, it is inferred that the manipulation of fertilizer rates and weed management practices manifested significant variations on wheat traits. It was evidenced that agronomic and physiological traits of wheat along with nutrient accumulation and uptake were increased when wheat crop was supplied with 135-90$50 \mathrm{NPK} \mathrm{kg} \mathrm{ha}{ }^{-1}$ and weed were controlled by 
herbicide application and hand hoeing. Consequently, these practices minimized weed crop competition and recorded higher wheat yield. The linear regression analysis between yield and yield components under the influence of different fertilizer rates and weed management practices were positive and significant which rectifies that enhancement in yield was due to the increase of all agronomic and physiological characteristics and higher nutrient uptake.

\section{Authors' contributions}

Conceived and designed the experiments: MA Babar, Performed the experiments: S Azam, Analyzed the data: A Jan \& A Khan, Contributed materials/ analysis/ tools: S Azam \& Ikramullah, Wrote the paper: MA Baber \& M Arif.

\section{References}

1. Brady NC \& Weil RR (2002). The Nature and Properties of Soils $\left(13^{\text {th }}\right.$ ed). Pearson Education Ltd., USA. pp 960.

2. Brown BD \& Petrie S (2006). Irrigated hard winter wheat response to fall, spring, and late season applied nitrogen. Field Crop Res 96: 260-268.

3. Liang XQ, Li H, He MM, Chen YX, Tian GM \& Xu SY (2008). The ecologically optimum application of nitrogen in wheat season of rice- wheat cropping system. Agron J 100: 67-72.

4. Sobh MM, Sharshar MS \& Soad El-Said A (2000). Response of wheat to nitrogen and potassium application in a salt affected soil. $J$ Product and Dev 5(1): 83-98.

5. Alam MS, Nesa MN, Khan SK, Hossain MB \& Hoque A (2007). Varietal differences on yield and yield contributing characters of wheat under different levels of nitrogen and planting methods. J App Sci Res 1388-1392.

6. Kumar R, Aggarwal SK \& Nanwal RK (2007). Effect of planting systems, seed rates and nitrogen levels on bread wheat (Triticum aestivum). Ind J Agric Sci 77(10): 669-671.

7. Chauhan RS (2014). Effect of fertility and weed management on yield, nutrient uptake and economics of wheat. Ann Plant Soil Res 16(4): 304-307.

8. Kousar P, Liaqat A, Amber R, Ammarah M, Saman M, Sana R \& Nazish I (2015). Effect of different levels of nitrogen on the economic yield of wheat (Triticum aestivum L.) variety Aas-11. Inter J Agron Agric Res 6(3): 7-11.

9. Sharif $M$ (1985). Improvement of $P$ fertilizer efficiency. Proc. Inter. Seminar on Fertilizer Use Efficiency. Nov, 4-6, pp 10616.

10. Liakas V, Rauckis V \& Paltanaviius V (2001). Influence of phosphorus and potash fertilizers on germination, tillering and overwintering of winter wheat. Mokslo Darbai 74: 3-12.

11. Jiang ZQ, Feng ChaoNian, Huang LianLian, Guo WenShan, Zhu XinKai and Peng Yong Xin (2006). Effects of phosphorus application on dry matter production and phosphorus uptake in wheat (Triticum aestivum L.). Plant Nutr Fert Sci 12(5): 628-634.

12. Khalid S, Shafi M, Anwar S, Bakht J \& Khan AD (2004). Effect of nitrogen and phosphorus application on the yield and yield components of wheat. Sarhad J Agric 20(3): 347-353.

13. Wang J, Liu H, Wang S \& Han X (2003). Law of nutrient equilibrium, gain and loss in black soil farmland. Acta Pedol Sin 40: 246-251.

14. Bahmanyar MA \& Ranjbar GA (2008). The role of potassium in improving growth indices and increasing amount of grain nutrient elements of wheat cultivars. $J$ App Sci 8: 1280-1285.

15. Sharma KD, Nandwal AS \& Kuhad MS (1996). Potassium effects on $\mathrm{CO}_{2}$ exchange, ARA and yield of clusterbean cultivars under water stress. J Potassium Res 12: 412-423.

16. Egilla JN, Davies ET Jr \& Drew MC (2001). Effect of potassium on drought resistance of Hibiscus rosa-sinensis cv. Leprechaun: Plant growth, leaf macro and micronutrient content and root longevity. Plant Soil 229(2): 213- 224.

17. Ali LR, Aziz T, Maqsood MA, Kanwal S \& Ashraf M (2008). Pattern of potassium and 
sodium distribution in two cotton varieties. Pak J Agric Sci 45(1): 25-33.

18. Querke, E. 2006. Crop losses to pests. J Agric Sci 144: 31-43.

19. Al-Khatib K (1995). Weed control in wheat. Washington State University Cooperative Extension. Subject Code: 244, pp 364.

20. Javaid A, Bajwa R, Rabbani N \& Anjum T (2007). Comparative tolerance of six rice (Oryza sativa L.) genotypes to allelopathy of purple nutsedge (Cyperus rotundus L.). Allelopathy J 20(1): 157-166.

21. Bhowmik PC \& Doll JD (1992). Corn and soybean response to allelopathic effects of weed and crop residues. Agron J 74: 601606.

22. Bastiaans L, Paolini R \& Baumann DT (2008). Focus on ecological weed management: what is hindering adoption? Weed Res 48: 481-491.

23. Wright A, Egan S, Westrup J \& Grodecki A (2001). Weed management for successful plant establishment. Produced by Community Education and Extension support. NRM facts, vegetation series V 48. Department of Natural Resources and Mines, The state of Queensland.

24. Gibson LR (2000). Plant Competition. Agronomy Department, Iowa State University.

25. ABS (Australian Bureau of Statistics) (2008). Natural resource management on Australian farms: 4620.0 2006-7, Australian Bureau of Statistics, Canberra.

26. Cattanach G, Harris A \& Horris J (2013). Mapping Australia's Weed Management System, Publication number 13/019. Rural Industries Research and Development Corporation, Canberra.

27. Hassan G \& Marawat KB (2001). Integrated weed management in Agricultural crops. National Workshop on technologies for Sustainable Agri, Sep. 2426. NIAB, Faisalabad.

28. Chhokar RS, Ramesh KS \& Indu S (2012). Weed management strategies in wheat-A review. J Wheat Res 4(2): 1-21.

29. Travlos IS (2012). Reduced herbicide rates for an effective weed control in competitive wheat cultivars. Inter J Plant Prod 6(1):114.

30. Balyan RS, Malik RK \& Bhan VM (1988). Effects of time of application of isoproturon on the control of weeds in wheat (Triticum aestivum). Indian J Weed Sci 20: 10-14.

31. Naseer-ud-Din GM, Shehzad MA \& Nasrullah HM (2011). Efficacy of various pre and post emergence herbicides to control weeds in wheat. Pak J Agric Sci 48: 185-190.

32. Yongqing MA (2005). Allelopathic studies of common wheat (Triticum aestivum L). Weed Biol Manag 5: 93-104.

33. Harker KN \& John TO (2013). Recent weed control, weed management and integrated weed management. Weed Technol 27(1): 1-11.

34. Khan RA, Kaiser I, Atif H \& Showkat Z (2014). Effect of different concentrations of aqueous leaf extracts of some plants on the germination and seedling growth of maize (Zea mays) and wheat (Triticum aestivum). Int J Environ 3(3): 264-274.

35. Cheema ZA, Khaliq A \& Farooq R (2003). Efficacy of concentrated sorgaab alone and in combination with herbicides and a surfactant in wheat. J Animal Plant Sci 13(1): 10-13.

36. Bouyoucos GJ (1962). Hydrometer method improved for making particle-size analysis of soils. Agron J 53: 464-465.

37. McKeague JA (Ed.) (1978). Manual on soil sampling and methods of analysis. Can Soc soil Sci pp 66-68.

38. McLean EO (1982). Soil $\mathrm{pH}$ and lime requirement In: Page, A.L. (Ed.), Methods of soil analysis, Part 2: chemical and microbiological properties. Am Soc Agron Madison, WI (USA), pp 199-224.

39. Walkley A (1947) A critical examination of rapid method for exterminating organic carbon in soil:Effect of variations in digestion conditions and of organic soil constituents. Soil Sci 63: 251-263.

40. Black CA (1993). Soil fertility evaluation and control. Lewis publishers, Boca Raton, Florida, USA.

41. Soltanpour, PN \& Schwab AP (Eds.) (1977). A new soil test for simultaneous extraction of macro-micro nutrients in 
alkaline soils. Commun Soil Sci Plant Anal 8: 195-207.

42. Sonneveld C \& Van Dijk PA (1982). The effectiveness of some washing procedures on the removal of contaminates from plant tissues of glass house crops. Commun Soil Sci Plant Anal 13: 487-496.

43. Wolf B (1982). A comprehensive system of leaf analysis and its use for diagnosing crop nutrient status. Commun Soil Sci Plant Anal 13: 1035-1059.

44. Cottenie A (1980). Soil and Plant testing as a basis of fertilizer recommendations. FAO soil Bulletin 38/2. Differences de techniques. Fruits 32: 151-166.

45. Knudsen D, Peterson GA \& Pratt PF (1982). Lithium, sodium and potassium. P. 225-245. In: L page A (Ed.), Methods of Soil Analysis, Part 2: Chemical and microbiological properties. Am Soc Agron Madison WI (USA).

46. Jones JB (1991). Kjeldahl method for nitrogen determination. Micro-Macro Publishing Inc., Athens, GA, USA.

47. Kalsoom UE et al. (2012). Response of maize and three perennial weeds to different combinations of macro-nutrients. Pak J Weed Sci Res 18 (4): 433-443.

48. Sandhya S, Bafina A \& Maheshwari R (2014). Effect of combinations of different chemical fertilizers on growth parameters and chlorophyll of wheat (Triticum aestivum L. GW 366). Int J Agric Crop Sci 7(14): 1371-1377.

49. Mubeen K, Nadeem MA, Tanveer A \& Jhala AJ (2014). Effect of seeding time and weed control methods in direct seeded rice (Oryza sativa L.). The J Animal Plant Sci 24(2): 534-542.
50. Iqbal J \& D Wright (1999). Effects of weed competition on flag leaf photosynthesis and grain yield of spring wheat. J Agric Sci 132(1): 23-30.

51. Ashraf U, Shakeel AA, Ehsanullah, Imran K \& Mohsin T (2014). Planting geometryinduced alteration in weed infestation, growth and yield of puddled rice. Pak $J$ Weed Sci Res 20(1): 77-89.

52. Islam $\mathrm{T}$, Bhowmic MK, Ghosh RK \& Sounda G (2000). Effect of pretilachlor on weed control and yield of transplanted rice. Environ Ecol 19: 265-268.

53. Girma K (1998). Interference of wild mustard (Sinapis arvenis L.) in spring wheat (Triticum aestivum L.). Graduate Thesis, Faculty of Graduate Studies, University of Guelph, Canada.

54. Fischer RA (1985). Number of kemels in wheat crops and the influence of solar radiation and temperature. J Agric Sci 105: 447-461.

55. Pourreza J, Bahrani A \& Karami S (2010). Effect of nitrogen fertilization application on stimulating wheat (Triticum aestivum) yield loss caused by wild oat (Avena fatua) interference. Am-Eurasian J Agric Environ Sci 9(1): 55-61.

56. Sary GA, El-Naggar HM, Kabesh MO, Elkramany MF \& Bakhoum GSH (2009). Effect of Bio-organic Fertilization and Some Weed Control Treatments on Yield and Yield Components of Wheat. World $J$ Agric Sci 5(1): 55-62.

57. Singh T (2014). Evaluation of different herbicides with NPK on growth and yield of wheat (Triticum aestivum L.) in field trial of Aligarh soil. Int J Sci Res 3(9): 2334-2336. 